\title{
電気の力で細菌をキャッチ! 電気的手法による細菌の簡易検出
}

O HACCP, 細菌検出, 誘電泳動, インピーダンス, DEPIM, 蒾垢細菌

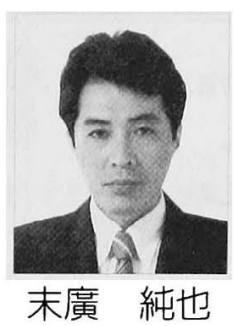

\section{1.はじめに}

夏の盛りを迎え，連日の猛暑でいささか复バテ気味… こんな時, ついつい冷たい飲み物や食べ物ばかりに手が伸 びがちだが，おなかの調子も気になるもの。暴飲暴食はさ ておき，夏は食中毒に注意が必要である。高温多湿の日本 の夏は, 食中毒の原因となる細菌にとってはすこぶる快適 な季節なのである。1996 年, 我が国では病原性大腸菌 O 157 による集団食中毒により，死者 12 名，発症者 9,451 名を記録した。その後, 患者数は減少したが根絶されたわ けではなく, 現在でも感染例が散発的に報告されている。 さらに 2000 年には, 食品への細菌や毒物などの異物混入 事件が相次ぎ，ずさんな品質管理体制など食品製造企業の イメージダウンにつながる社会問題に発展したことは記憶 に新しい。

これらはいささか極端な事例だが, 我々が毎日攝取する 食品の安全性が今改めて問われていることは間違いない。 このような状況のもと, 食品の品質管理にも新たな手法が 導入されるようになってきた。従来の品質管理は, 最終製 品の抜き取り検査が中心であり, 細菌検出には長時間を要 する培養法 (後述) が用いられているため, 検査結果が判 明する時にはすでに製品は出荷後となっていた。したがっ て, 製品不良が発生した場合に事後処理しかできず, 被害 の拡大を末然に抑えることは困難である。このような問題 点を解消するために導入が進められている品質管理法が HACCP (Hazard Analysis Critical Control Point, 八サ ップ）方式である。HACCP は, 食品の安全性を確保す るためにこれらにかかわる危害を確認し, それらを防除す る管理手法として定義されている。 HACCPでは, 原料

すえひろ・じゅんや (正員) 1985 年 3 月九州大学大学院修 士課程修了。同年 4 月新日本製鐵(株) 入社, 1988 年 4 月九州 大学工学部助手。現在九州大学大学院システム情報科学研究院 助教授。主として, 電力工学, 静電気応用工学, 超伝導工学に 関する研究に従事。博士 (工学)。
の入荷から加工・出荷の全工程において, あらかじめ決め られた重要管理事項が継続的に監視・記録される。したが って, 異常が認められると直ちに対策を講じることが可能 であり，不良品の出荷を末然に防ぐことができる。

欧米諸国ではすでに食品製造業者に HACCP が義務づ けられており, 我が国でもレトルト食品など一部品目が HACCP 承認品目として指定されている。HACCP の導 入により検査項目や回数が大幅に増えるため, 簡易・迅 速・低コストでかつ自動化が可能な細菌検査法が強く求め られている(1)。筆者は,このような要求にこたえ得る可能 性を有している電気的な細菌検出法について研究を行って いるが, 本稿ではその内容を紹介する。

\section{2. どうやって細菌を見つける?}

主な細菌検出法を表 1 に示す。さまざまな方法が存在す るが, 従来から最も広く用いられているのが「培養法」で ある。細菌の大きさは $1 \mu \mathrm{m}$ オーダであり, 光学顕微鏡の 検出下限に近い。特に濃度が低い場合には，顕微鏡では見 落とす可能性が高い。細菌の増殖に必要な栄養素を含んだ 固体媒質（培地と呼ぶ。寒天が一般的）の表面に細菌を含 んだ試料液を散布すると, 細菌は時間とともに增殖を始 め, 1 個の細菌が肉眼で観察できるほどの集落（コロニ 一) を形成する（図 1)。懸濁液を適度に希釈し，1個の細 菌が 1 個のコロニーを形成するようにしておけば, コロニ 一の数と希釈倍率から元の懸濁液の菌濃度を算出できる。 さらに, 培地の成分を調整して特定の細菌のみが増殖する ようにしておけば，選択的検出も可能である。しかしなが ら, 培養法では細菌の増殖を待つ必要があるため, 結果が 出るまでに2〜3 日程度の長時間を要することが最大の久 点である。したがって, 現在研究開発が行われている新し い検出法では, 検出の迅速化が重要な課題の一つとなって いる。

そのほかに細菌検出に求められる性能としては, 以下の ようなものが挙げられる。

・選択性（病原性の細菌や生きている菌のみを検出） 
表 1 細菌検出法の分類

\begin{tabular}{|c|c|c|c|}
\hline 分 類 & 称 & 原 & 徵 ○長所 短所 \\
\hline 生物 & 培養法 & $\begin{array}{l}\text { 寒天培地上で細菌を増殖させ，形成される集落（コロ } \\
\text { ニー）を計数 }\end{array}$ & $\begin{array}{l}\text { ○生菌のみを検出できる } \\
\text { ○培地の成分を調整することで選択的検出が叮能 } \\
\text { 長時間（数日）を要す }\end{array}$ \\
\hline 光 & 比濁法 & 細菌による光の散乱, 吸収 & $\begin{array}{l}\text { ○簡易, 迅速 } \\
\text { ○污濁液中では感度低下 }\end{array}$ \\
\hline 電気 & インピーダンス法 & 細菌または細菌生成物質のインピーダンスを検出 & $\begin{array}{l}\text { ○簡易, 自動化 } \\
\text { ○選択性が低い }\end{array}$ \\
\hline 生化学 & ATP 法 & $\begin{array}{l}\text { 細菌に含まれるATP (アデノシン三リン酸)を抽出 } \\
\text { し，蛍光検出 } \\
\text { 細菌に特異的に結命する抗体を利用。凝集や酵素反応 } \\
\text { により検出 }\end{array}$ & $\begin{array}{l}\text { O高感度 } \\
\text { ○選択性が低い（ATP は食品残渣などにも含まれる) } \\
\text { ○高感度 } \\
\text { ○高選択性 } \\
\text { の高コスト（試薬） }\end{array}$ \\
\hline & PCR 法 & $\begin{array}{l}\text { ポリメラーゼ連鎖反応により細菌の DNA を増幅し, } \\
\text { 蛍光検出 }\end{array}$ & $\begin{array}{l}\text { ○高選択性（遺伝子レベル） } \\
\text { 生菌, 死菌の選択不可 }\end{array}$ \\
\hline
\end{tabular}

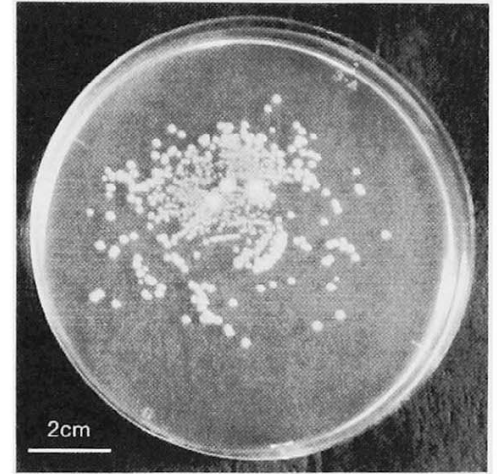

図 1 培地上で成長した大腸菌コロニー (48 時間培養)

- 高感度

・簡便，低コスト（検体量が多い場合には特に重要）

\section{3. 電気的な細菌検出法}

電気的な現象を利用して生体物質を分離・検山する方法 は, 従来から幅広く利用されている。分離技術の代表例と しては, DNAの分離検出に利用されている電気泳動法が ある。一方, 細菌など微生物の電気的検出法には, 表 1 に も挙げたインピーダンス法がある。その一例として，血球 数の計数装置として血液検查などに広く用いられているコ ールターカウンター®の原理を図 2 に示す。小さな穴が貫 通している絶縁物の隔壁で仕切られた二つの容器は電解質 溶液で満たされており, 片方に検出対象の血球を䋰濁して おく。各々の容器にセットされた電極に直流電圧を印加す ると, 通常負極性に帯電している血球は電気泳動により陰 極側から陽極側へ移動する。この時，電極間を流れる電流 は穴の部分に集中し，穴の内部を絶縁物である血球が通過 すると電流が遮られるため, 電極間の見かけの抵抗がパル

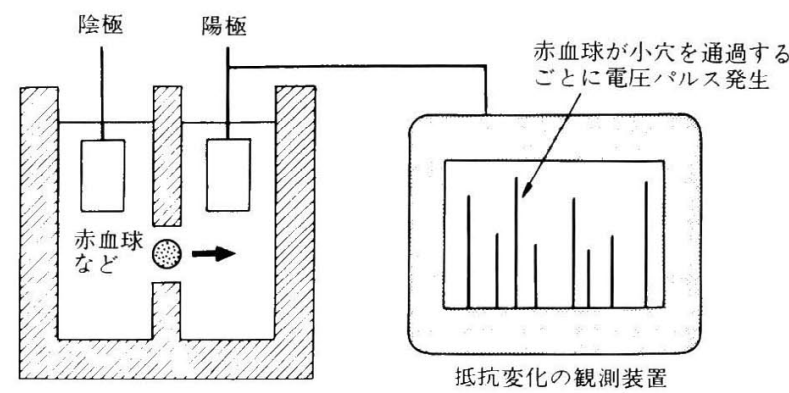

図 2 コールターカウンター®の原理

ス的に変化する。このパルスをカウントすれば血球数を知 ることができる。また，抵抗変化は血球の体積に比例する ため, 血球の大きさについての情報も同時に得ることがで きる。

このように，インピーダンス法では微生物を「生物」と してではなく, 電気的に等価な「誘電体粒子」として検出 している点が特徵である。電気的な微生物検出法は, 検出 の迅速化・簡易化などの点で大きなメリットがある。

\section{4. 電気の力で細菌を集める}

筆者らは, 細菌の検出だけでなく濃縮も電気的に行うこ とができる新しい測定法について研究を行っている(2)。同 測定法は図 3 に示すように, 誘電泳動現象により細菌を濃 縮し, 濃縮した細菌を電気インピーダンスにより検出する もので, 誘電泳動インピーダンス計測法 (Dielectrophoretic Impedance Measurement, DEPIM) と呼ばれ る。菌濃縮により検出の迅速化および高感度化を実現して いる。

\section{1 誘電泳動現象}

細菌の懸濁液中に外部電界を印加すると, 懸濁液と細菌 


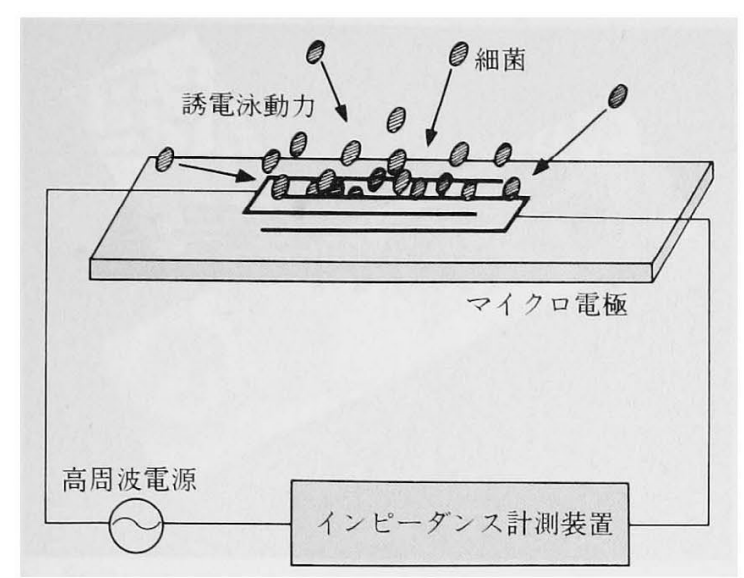

図 3 誘電泳動インピーダンス計測法 (DEPIM)

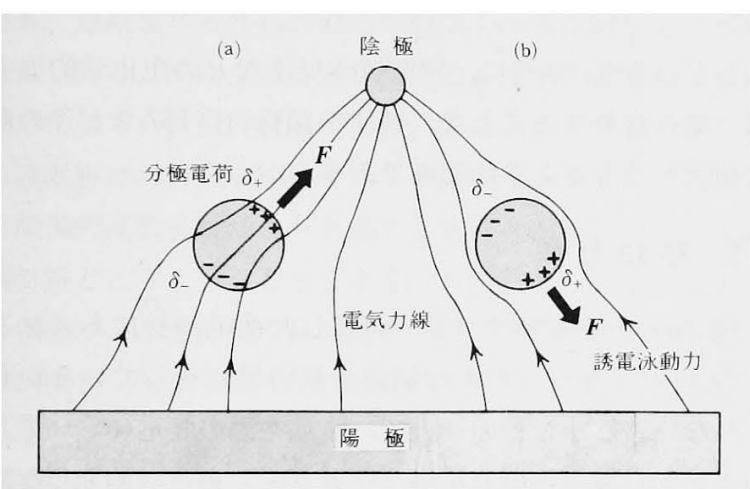

図 4 誘電泳動現象

はともに分極する。その結果，細菌の表面には分極電荷が 誘起されるが，その極性や大きさはそれぞれの分極の程度 によって変化する。細菌の方が懸濁液よりも分極しやすい 場合には，対向電極と逆極性の分極電荷が誘起され，その 結果細菌内部には外部電界と同方向の双極子モーメントが 発生する(図 4(a))。懸濁液の方が分極しやすけ机ば, 双極子モーメントの方向は電界と逆方向となる（図 4(b))。

外部電界が平等電界の場合, 正負の分極電荷に作用する クーロン力は大きさが等しく逆向きとなるため, 細菌には 正味の力は作用しない。一方，不平等電界下では，正負分 極電荷に作用するクーロン力が釣り合わず，細菌全体に正 味の力が作用する。このように，不平等電界中で分極した 誘電体粒子に作用する力を誘電泳動力と呼ぶ(3)。

図 4 (a) の場合には, 分極電荷と対向電極の間には吸引 力が働くため, 誘電泳動力は高電界方向となり,これを正 の誘電泳動と呼ぶ。図 4(b) の場合には, 分極電荷は対向 電極から反発力を受けるため, 誘電泳動力は低電界方向と なり，これを負の誘電泳動と呼ぶ。このように誘電泳動力 は, 電界分布, 電界周波数, 細菌や㲘濁液の誘電特性など
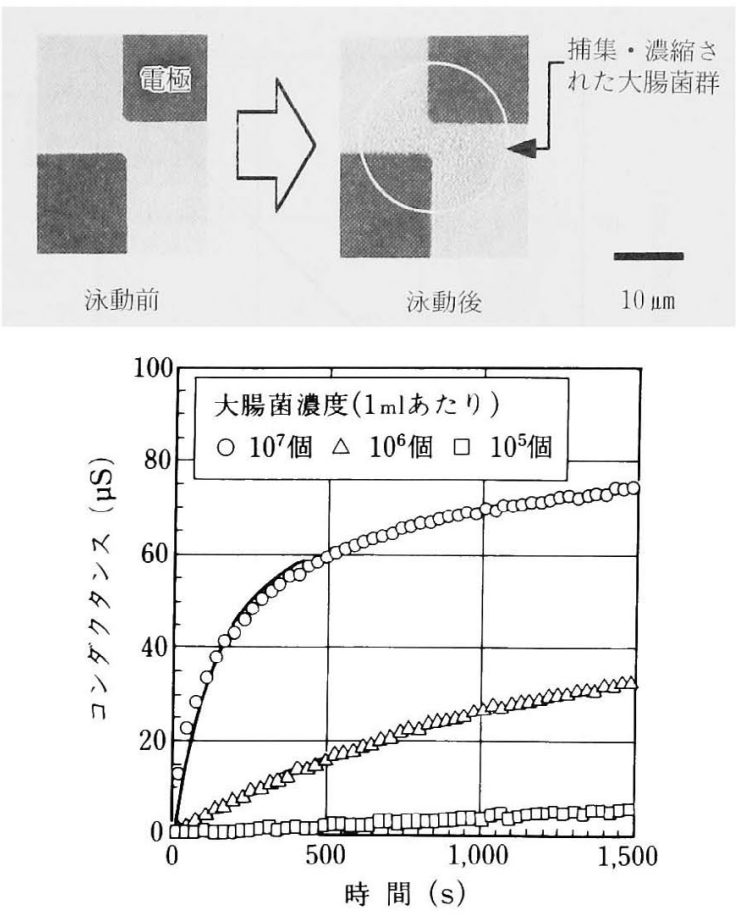

図 5 DEPIM による大腸菌の濃縮とインピーダンス变化

に強い依存性を示す ${ }^{(4)}$ 。

\section{2 誘電泳動インピーダンス計測法}

正の誘電泳動を利用して細菌を高電界領域に駆動する と, 細菌の濃縮が起こる。誘電泳動インピーダンス計測法 では，ガラス基板上にフォトリソグラフィによって作製し たマイクロ電極を用いて高電界を発生させる。1 $\mathrm{m}$ オー ダのギャップを有するマイクロ電極では, $1 \mathrm{MV} / \mathrm{m}$ 程度 の高電界領域を数 V の印加電圧で容易に発生でき(5), ギ ヤップ間に細菌を捕集し濃縮できる。

誘電泳動で捕集された細菌は，ギャップ間で規則正しく 電界方向に整列し，パールチェーンと呼ばれる数珠状の集 合体を形成する。捕集された細菌全体のインピーダンス は, 細菌一つのインピーダンスの合成インピーダンスとし て表すことができるので，菌濃縮に伴う電極間インピーダ ンスの変化を測定すれば, 捕集された細菌の数, ひいては 懸濁液中の菌濃度を推定できる。

DEPIM 法を用いて大腸菌を検出した結果を図 5 に示 す。菌濃度にもよるが, 30 分以内で菌捕集に伴うインピ ーダンス（図ではコンダクタンス成分を表示している）の 変化が認められ, 迅速な検出が可能であることが分かる。 この時, マイクロ電極内の電界集中部では, 同図内に示す ように正の誘電泳動により大腸菌が濃縮される。菌濃度が 高いほど単位時間あたりに多くの藏が捕集されるため, 泳 動開始直後のインピーダンス時間変化率が大きくなってい ることが分かる。この特性を利用して, 菌濃度を定量する ことが可能であり, 現時点で $1 \mathrm{ml}$ あたり 1,000 個程度の 


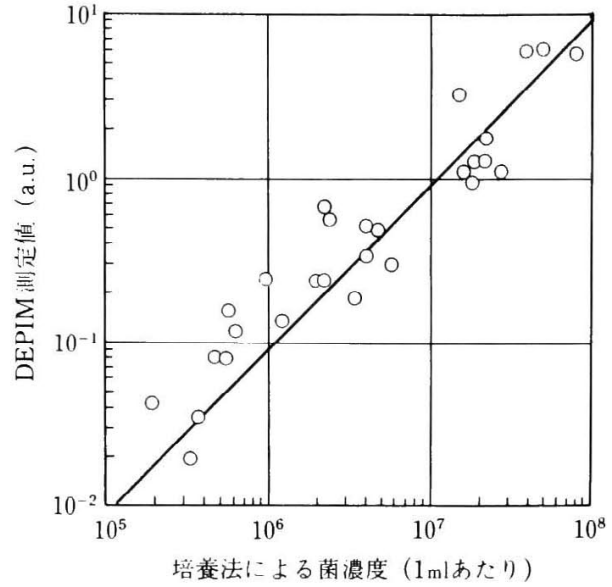

図 6 DEPIMによる歯垢細菌の検出（培養法との比較）

大腸菌を検出することができる。

\section{3 応用例}

細菌の検出が必要とされる分野は, 食品製造ラインだけ にとどまらない。例えば，医療の臨床検査においても，血 液、尿，口腔などに含まれる細菌検査は重要である。迅速 かつ簡便である DEPIM 法の特徵を生かして, 診察時に 細菌検查を行い検查結果を反映した的確な措置をその場で 医師が患者に施すことができるようになるだろう。

筆者らはこのような試みの一環として，う蝕（虫歯）の リスク判定材料として, 窲に付着した歯垢中の細菌を DEPIM 法で検出・定量する試みを行っている(6)。図6は 複数の被験者から採集した歯垢中の菌数をDEPIM 法て 計測した結果を培養法と比較した結果である。DEPIM 法 に要する時間はわずか 1 分であるが，培養には 48 時間を 要す。歯垢中には多種の細菌が含まれているにもかかわら ず，DEPIM 法の検出結果は培養法の結果と強い相関を示 している。図 6 のようなデー夕を検量線として蓄積すれ ば，他の分野でもDEPIMによる定量的な細菌検査が可 能となるであろう。

DEPIM 法は装置構成が簡単で試薬なども必要としない ため，簡便で低コストな検出装置を実現できることもメり ットである。すでに図7に示すようなポータブルタイプの 小型装置が試作されており, さらなる応用範囲の拡大が期 待される。

2 章でも述べたように, 細菌検出には選択性が要求され る場合が多い。細菌を等価誘電体として検出する DEPIM 法では, 異なる誘電特性を持つ細菌であれば選択的に検出 することができる。筆者らは, 大腸菌の生菌と死菌の誘電 特性の違いを利用して, 両者を選択的に検出することに成

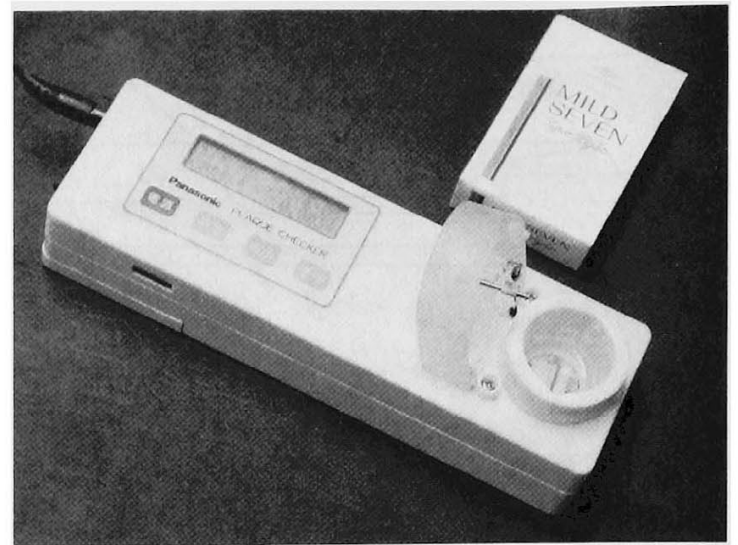

写真提供：パナソニックヘレウスデンタル(株)

図 7 ボータブル型 DEPIM 装置

功している(7)。さらに, 抗原抗体反応などの生化学的な手 法と組み合わせることで，特定の菌株（O 157 など）の選 択検出もできるようになるであろう。

\section{5.おわりに}

「抗菌」をキャッチフレーズにした商品が巷にあふれる 昨今,「バイキン」たちは肩身の狭い思いをしているかも しれない。しかしその一方で，食品や酒の製造において人 類は昔から微生物の力を借りてきたのである。紹介した電 気的な細菌検出技術は，バイオプロセスにおけるこれら有 用微生物のモニタリングにも利用できる可能性を有してい る。

(平成 13 年 5 月 9 日受付)

（1）「食品と開発」編集部：「微生物検植技術の最新動向」，食品と開 発, 36, 32 37 (2001)

( 2 ) J J. Suehiro, R. Yatsunami, R. Hamada, \& M. Hara: "Quantitative Estimation of Biological Cell Concentration Suspended in Aqueous Medium by Using Dielectrophoretic Impedance Measurement Method", J. Phys. D: Appl. Phys., 32, 2814 2820 (1999)

(3) H. A. Pohl : "Dielectrophoresis", Cambrdge University Press (1978)

(4) R. Pethig: "Dielectrophoresis: Using Inhomogeneous AC Electrical Fields to Separate and Manipulate Cells", Crit. Rev. Bintechnol., 16, 331 348 (1996)

(5) M. Washizu, S. Suzuki, O. Kurosawa, T. Nishizaka, \& T Shinohara: "Molecular Dielectrophoresis of Biopolymers", IEEE Trans. Industry Applicat., 30, 835 843 (1994)

（6）西川原・山田・山根・有本・田・末廣・西尾：「力リエスリス ク診断に関する研究〜誘電泳動法による歯垢内細菌測定の試み 日本歯科保存学会 2001 年度春季学会抄録集 (2001)

(7) R. Hamada, D. Noutomi, J. Suehiro, R. Yatsunami, \& M Hara : "Selective Detection of Viable and Non-viable Bacteria by Using Dielectrophoretic Impedance Measurement Method", Proc, of Int. Conf. on Electrical Engineering 2000, 1081 1084 (2000) 